\title{
Deleterious ERCC3 Gene Mutation
}

National Cancer Institute

\section{Source}

National Cancer Institute. Deleterious ERCC3 Gene Mutation. NCI Thesaurus. Code

C156012.

A change in the nucleotide sequence of the ERCC3 gene that is associated with increased risk of disease. 